\title{
Isolation and Some Properties of Temperature-sensitive Mutants of Micrococcus radiodurans Defective in DNA Synthesis
}

\author{
By B. E. B. MOSELEY, ALICE MATTINGLY AND MERYL SHIMMIN \\ Department of General Microbiology, University of Edinburgh \\ College of Agriculture, Edinburgh, $\mathrm{EH}_{9}{ }_{3} \mathrm{JG}$
}

(Accepted for publication 23 November 197I)

\begin{abstract}
SUMMARY
Three temperature-sensitive mutants of Micrococcus radiodurans have been isolated which, unlike the wild-type, are unable to synthesize DNA at $39^{\circ}$. Synthesis of DNA stops immediately the bacteria are raised to the restrictive temperature. The mutants can be transformed normally for single genetic markers and can regain wild-type temperature resistance on incubation with DNA from wild-type at a frequency associated with single or very closely linked markers. Each mutant can also be transformed to wild-type temperature resistance with DNA from the other temperature-sensitive mutants. All three mutants are resistant to the lethal action of ionizing and ultraviolet radiations and at $39^{\circ}$ are able to carry out all or most of the DNA repair functions associated with excision repair, but at a reduced rate compared with wild-type. The rate of excision at $39^{\circ}$ of u.v.-induced thyminecontaining pyrimidine dimers is four to five times slower in the mutants than in the wild-type.
\end{abstract}

\section{INTRODUCTION}

Micrococcus radiodurans is very resistant to the lethal action of ionizing and ultraviolet radiation (Anderson et al. 1956; Duggan, Anderson, Elliker \& Cain, 1959), and to some other agents which cause single-strand damage to DNA, such as $N$-methyl- $N^{\prime}$-nitro- $N$ nitrosoguanidine (Moseley, I967), nitrous acid and hydroxylamine (unpublished observation). Its ability to recover from the action of these agents depends upon its DNA repair mechanisms. It has a very efficient excision repair mechanism with which it can excise from its DNA u.v.-induced pyrimidine dimers which could otherwise be lethal (Boling \& Setlow, 1966) and presumably other altered bases (Hanawalt \& Haynes, 1965). It also possesses a post-replication repair mechanism (Moseley \& Mattingly, 197I) by which any unexcised dimers are effectively by-passed in the DNA by recombination, a mechanism discovered originally in Escherichia coli by Rupp \& Howard-Flanders (I968). This mechanism appears to be defective in $E$. coli having a mutation in the lex or exr locus (Witkin, 1969) and in the mutant u.v. I7 of $M$. radiodurans (Moseley \& Mattingly, I97I).

Temperature-sensitive mutants of Escherichia coli have been isolated which are unable to replicate their DNA at $42^{\circ}$ (Bonhoeffer \& Schaller, I965), but which nevertheless are able to carry out unscheduled DNA synthesis, indicative of repair (Pettijohn \& Hanawalt, 1964), at the restrictive temperature (Couch \& Hanawalt, 1967). This paper describes the isolation of temperature-sensitive mutants of Micrococcus radiodurans which are unable to replicate their DNA at $39^{\circ}$, and some of their properties. 


\section{METHODS}

Bacteria. The strain of Micrococcus radiodurans used was that originally isolated by Anderson et al. (1956).

Media. TGY broth for growth contained Bactotryptone (Difco), $5 \mathrm{~g}$; glucose, I g; yeast extract (Difco), $3 \mathrm{~g}$; distilled water, I l. TGY agar for colony counts and replica plating was made by solidifying this medium with $15 \mathrm{~g}$ Bactoagar/l.

An $\mathrm{M} / \mathrm{I} 5$ phosphate buffer, $\mathrm{pH} 7 \cdot 0$, was used for washing bacteria and for suspending them during irradiation. It contained $\mathrm{Na}_{2} \mathrm{HPO}_{4}, 4 \cdot 73 \mathrm{~g} ; \mathrm{KH}_{2} \mathrm{PO}_{4}, 4.54 \mathrm{~g}$; distilled water, $\mathrm{I} 1$.

Measurement of growth rates. Samples from $18 \mathrm{~h}$ cultures were diluted into $20 \mathrm{ml}$ quantities of TGY broth to give a turbidity reading of about 0.08 in a nephelometer (Evans Electroselenium Ltd, Halstead, Essex) using an orange filter (this turbidity was equal to a concentration of $2.5 \times 10^{7}$ viable units $/ \mathrm{ml}$ ) and the cultures swirled in flasks at $30^{\circ}$. Turbidity readings were taken at various times until they reached about $0.80\left(3^{\circ} 0 \times 10^{8}\right.$ viable units $/ \mathrm{ml}$ ). The doubling times were calculated from the plotted data.

Preparation of bacteria for irradiation. Overnight cultures were diluted with TGY broth to a turbidity reading of 0.08 and swirled in flasks at $30^{\circ}$ until the turbidities reached 0.50 to 0.55 (about $\mathrm{I} .5 \times 10^{8}$ viable units $/ \mathrm{ml}$ ). The bacteria were centrifuged, washed, and resuspended in chilled $\mathrm{M} / \mathrm{I} 5$ phosphate buffer at a concentration of about $1 \cdot 0 \times 10^{8}$ viable units/ $\mathrm{ml}$. For u.v. irradiation $5 \mathrm{ml}$ samples of the washed bacterial suspension were agitated by means of a magnetic stirrer and irradiated in Petri dishes $(9 \mathrm{~cm}$ diam) at a distance of $40 \mathrm{~cm}$ from a Hanovia germicidal lamp (model I2). The incident dose rate was $22.5 \mathrm{ergs} / \mathrm{mm}^{2} / \mathrm{s}$. At intervals $0.1 \mathrm{ml}$ samples were removed, suitably diluted into chilled TGY and $0.1 \mathrm{ml}$ samples spread on TGY agar plates. Colonies derived from surviving cells were counted after incubation at $30^{\circ}$ for two days.

$\gamma$-Irradiation was carried out in a ${ }^{60} \mathrm{Co}$ source at a dose rate of 7.5 to $8.0 \mathrm{krad} / \mathrm{min}$. Three $\mathrm{ml}$ volumes of the washed bacterial suspension were irradiated, oxygen being bubbled during the irradiation. Samples were removed and viability measured in the same way as for u.v. irradiation.

Isolation of temperature-sensitive mutants. The procedure used was based on the method used to isolate radiation-sensitive mutants of Micrococcus radiodurans (Moseley 1967). Five $\mathrm{ml}$ of a $\log$ phase culture at a turbidity of $0.38\left(\mathrm{I} \cdot 0 \times 10^{8}\right.$ viable units $\left./ \mathrm{ml}\right)$ was washed and resuspended in $5 \mathrm{ml} \mathrm{M} / \mathrm{I} 5$ phosphate buffer and irradiated with $10000 \mathrm{ergs} / \mathrm{mm}^{2} \mathrm{u} . v$. radiation. Four $\mathrm{ml}$ of the irradiated suspension was added to $5 \mathrm{ml}$ TGY broth and swirled at $30^{\circ}$ for $30 \mathrm{~min}$. One $\mathrm{ml}$ of $N$-methyl- $N^{\prime}$-nitro- $N$-nitrosoguanidine (NG) solution was then added to give a final concentration of $100 \mu \mathrm{g} \mathrm{NG} / \mathrm{ml}$. After incubation for a further $45 \mathrm{~min}$, $0.2 \mathrm{ml}$ of this culture was diluted roo-fold in TGY broth, to dilute out the mutagen, and incubated at $30^{\circ}$ overnight. The culture was then suitably diluted and $0 \cdot 1 \mathrm{ml} \mathrm{samples} \mathrm{spread}$ on TGY plates to give about 80 to roo colonies per plate after incubation at $30^{\circ}$ for 2 days. Two replicate copies of each plate were made, one incubated at $39^{\circ}$ and one at $30^{\circ}$. After incubation for $24 \mathrm{~h}$, colonies which grew at $30^{\circ}$ but not at $39^{\circ}$ were isolated and inability to grow at $39^{\circ}$ was confirmed.

Measurement of DNA, RNA and protein synthesis. Samples of the wild-type and the temperature-sensitive mutants were grown to a turbidity of about 0.30 . To $0.12 \mathrm{ml}$ quantities of the cultures were added equal quantities of TGY broth and an appropriate radioactive compound: $5 \mu \mathrm{Ci}$ tritiated thymidine $\left(\left[{ }^{3} \mathrm{H}\right] \mathrm{dT}\right.$ specific activity $\left.14 \mathrm{Ci} / \mathrm{mM}\right)$ to measure DNA synthesis, $5 \mu \mathrm{Ci}$ tritiated uridine $\left(\left[{ }^{3} \mathrm{H}\right] \mathrm{U}\right.$ specific activity $\left.17 \mathrm{Ci} / \mathrm{mm}\right)$ to measure RNA synthesis, or $\left[{ }^{14} \mathrm{C}\right]$ methionine to measure protein synthesis. To measure synthesis at 
$30^{\circ}$ and $39^{\circ}$ duplicate cultures were incubated at $30^{\circ}$ for $80 \mathrm{~min}$ before one of each pair of tubes was raised to the restrictive temperature of $39^{\circ}$. The amount of radioactivity in the trichloracetic acid-insoluble fraction of the bacteria was measured as a function of time by the paper-disc method of Bollum (I959).

Genetic transformation of the temperature-sensitive strains. The procedure was basically that described by Moseley \& Mattingly (I97I). Assay tubes were set up containing $0.05 \mathrm{ml}$ autoclaved extract of Micrococcus radiodurans, $0.05 \mathrm{ml}$ DNA and $0.20 \mathrm{ml}$ recipient bacteria. The assay tubes were incubated at $30^{\circ}$ for $3 \mathrm{~h}$ and diluted tenfold by the addition of $2.7 \mathrm{ml}$ chilled TGY broth. Then $\mathrm{I} \cdot 0 \mathrm{ml}$ quantities were placed in Petri dishes and $9 \mathrm{ml}$ amounts of molten TGY agar at $46^{\circ}$ were added to each. The plates were swirled several times to ensure even distribution of the cells and the agar allowed to solidify. For transformation to wild-type temperature resistance a second layer of $\mathrm{I} 0 \mathrm{ml}$ molten agar was added, allowed to solidify and the plates were incubated at $39^{\circ}$. For transformation to streptomycin resistance a second layer of agar containing $200 \mu \mathrm{g}$ streptomycin $/ \mathrm{ml}$ was added and the plates incubated at $30^{\circ}$. Transformant colonies were counted after 4 to 5 days of incubation. Control plates from assay tubes containing no DNA were included in each experiment.

Removal of pyrimidine-dimers from DNA at the restrictive temperature. Five $0.5 \mathrm{ml}$ samples from a control culture at a turbidity of 0.08 were put in test tubes, $25 \mu \mathrm{Ci}\left[{ }^{3} \mathrm{H}\right] \mathrm{dT}$ added to each, and the cultures incubated at $30^{\circ}$ until the turbidity in the control culture reached 0.60 to 0.70 . The cultures were spun down, washed, and each resuspended in $0.5 \mathrm{ml} \mathrm{M} / \mathrm{I} 5$ phosphate buffer. One culture was not irradiated. The four remaining cultures were irradiated with u.v. light, centrifuged and resuspended in $0.5 \mathrm{ml} \mathrm{TGY} \mathrm{broth.} \mathrm{Three} \mathrm{were} \mathrm{incu-}$ bated for varying periods of time at $39^{\circ}$ while the unirradiated and one irradiated sample were held in ice. The bacteria in each sample were centrifuged, washed in $M / 15$ phosphate buffer and suspended in $0.2 \mathrm{ml}$ buffer. Calf-thymus DNA (0.I ml at $4 \mathrm{mg} / \mathrm{ml}$ ) and $0.2 \mathrm{ml}$ cold $10 \%$ trichloracetic acid (TCA) were added to each tube and the contents mixed. After Io min the TCA precipitate was centrifuged and washed with $0.2 \mathrm{ml}$ cold $5 \%$ TCA. After centrifugation the TCA was removed and the precipitate washed with $95 \%$ ethyl alcohol and dried. Each sample was hydrolysed with $0.2 \mathrm{ml} 98 \%$ formic acid in a sealed hydrolysis tube at $175^{\circ}$ for $20 \mathrm{~min}$. The hydrolysis procedure converts thymine-cytosine dimers to thymine-uracil dimers (Setlow, Carrier \& Bollum, 1965), in which form they appear in subsequent chromatograms. The hydrolysed material was chromatographed by descending chromatography in two dimensions using butanol-acetic acid-water (80:12:30) for the first dimension and butanol-water (86: I4) for the second. In the first dimension thymine had an $R_{F}$ of 0.63 , the thymine-thymine dimer 0.29 and the thymine-uracil dimer 0.22 . The thymine region was assayed for radioactivity while the dimer region was run in the second dimension. The $R_{F}$ of both dimers was 0.09 , so that background counts were moved away from the dimer region. The dimer regions were cut into $\mathrm{I} \mathrm{cm}$ strips and the radioactivity was assayed. The radioactivity in the dimers was calculated as a percent of the total radioactivity in the TCA-insoluble fraction.

\section{RESULTS}

The restrictive temperature. Micrococcus radiodurans, when originally isolated, showed good growth at $37^{\circ}$ but none at $45^{\circ}$ (Anderson et al. 1956 ). In practice we incubate liquid cultures at $30^{\circ}$ because at $37^{\circ}$ the bacteria tend to aggregate into large clumps and the culture is difficult to use for quantitative studies. However, good growth of single viable units into colonies was obtained on agar plates at temperatures up to $39^{\circ}$. At $41^{\circ}$ there was no visible growth and so $39^{\circ}$ was chosen as a possible restrictive temperature. 


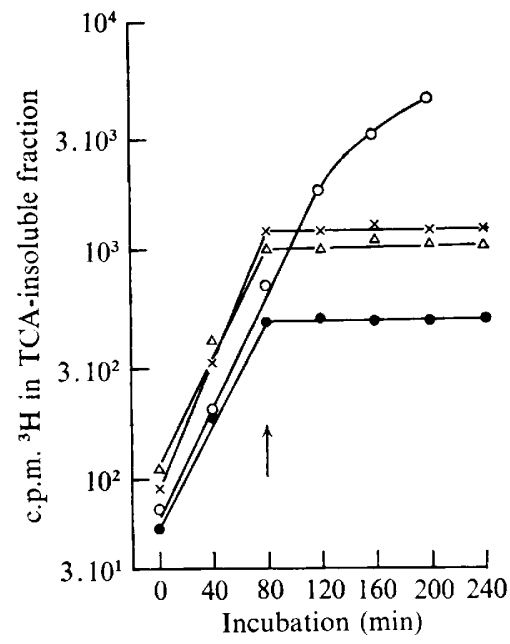

Fig. I

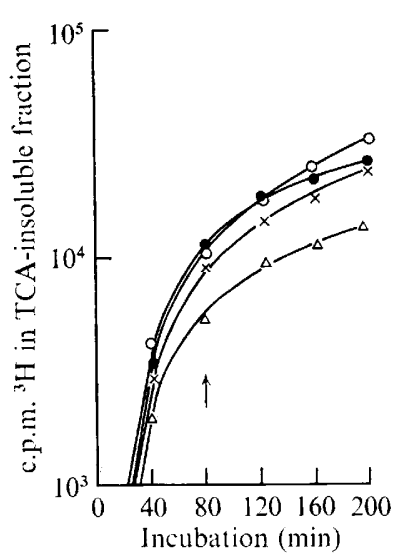

Fig. 2

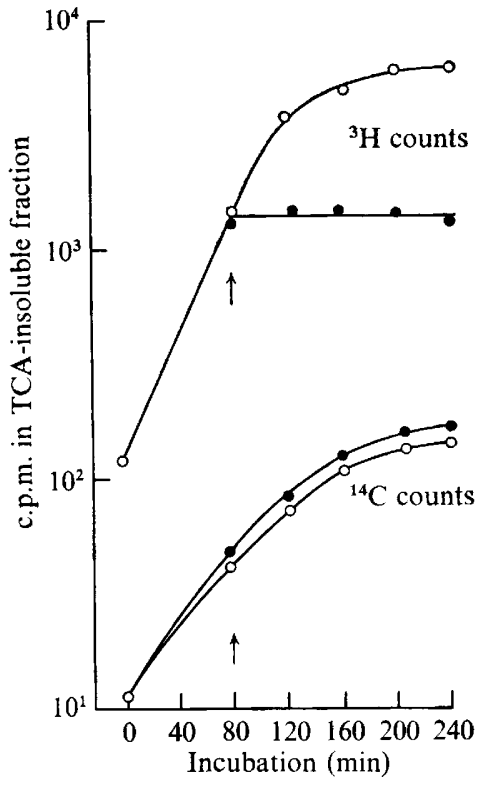

Fig. 3

Fig. I. Uptake of $\left[{ }^{3} \mathrm{H}\right]$ thymidine into the TCA-insoluble fraction of wild-type $(O)$ and the temperature-sensitive mutants tsI $(\times)$, ts2 $(\bullet)$ and ts $3(\triangle)$ of Micrococcus radiodurans as a measure of DNA synthesis. The temperature was raised to $39^{\circ}$ after $80 \mathrm{~min}$ at $30^{\circ}$ as indicated by the arrow.

Fig. 2. Uptake of [ $\left.{ }^{3} \mathrm{H}\right]$ uridine into the TCA-insoluble fraction of wild-type $(\mathrm{O})$ and the temperaturesensitive mutants tsI $(\times)$, ts2 $(\bullet)$ and ts $3(\triangle)$ of Micrococcus radiodurans as a measure of RNA synthesis. The temperature was raised from $30^{\circ}$ to $39^{\circ}$ after $80 \mathrm{~min}$.

Fig. 3. Uptake of $\left[{ }^{3} \mathrm{H}\right]$ thymidine and $\left[{ }^{14} \mathrm{C}\right]$ methionine in ts 3 as a measure of DNA and protein synthesis respectively. One culture was incubated at $30^{\circ}(O)$ and a second incubated at $30^{\circ}$ for $80 \mathrm{~min}$ and then at $39^{\circ}(\bullet)$. The upper part of the graph gives the results for ${ }^{3} \mathrm{H}$ 'assay and the lower those for ${ }^{14} \mathrm{C}$.

Isolation of mutants. Of about 6000 colonies derived from bacteria which survived the mutagenic treatment, I5 proved to have no growth at $39^{\circ}$ but growth rates comparable to the wild type at $30^{\circ}$. These 15 mutants were screened to select for those which were unable to grow at $39^{\circ}$ because of their inability to synthesize DNA at this temperature. On raising the temperature to $39^{\circ}$ after approximately one generation time at $30^{\circ}$, the incorporation of $\left[{ }^{3} \mathrm{H}\right]$ thymidine ceased in seven of the mutants. Of the seven, three have been examined in some detail. They have been designated Micrococcus radiodurans ts 1, ts 2 and ts 3 . The colonies of the wild-type and three mutants were similar in size and appearance and all contained the carotenoid pigment which has an absorption peak at $475 \mathrm{~nm}$. Morphologically the bacteria were identical.

The uptake of $\left[{ }^{3} \mathrm{H}\right]$ thymidine into the TCA-insoluble fraction of the bacteria, as a measure of DNA synthesis, is shown in Fig. I. Synthesis of DNA ceased immediately the mutants were raised to $39^{\circ}$ but continued in the wild-type. Fig. 2 shows the uptake of $\left[{ }^{3} \mathrm{H}\right]$ uridine, as a measure of RNA synthesis, which continued at $39^{\circ}$ in the wild-type and the mutants. Protein synthesis as measured by uptake of $\left[{ }^{14} \mathrm{C}\right]$ methionine also continued in all three mutants at the restrictive temperature and results are shown in Fig. 3 for the mutant ts 3 . 


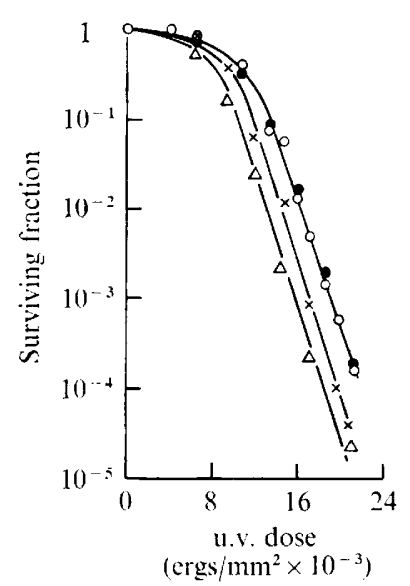

Fig. 4

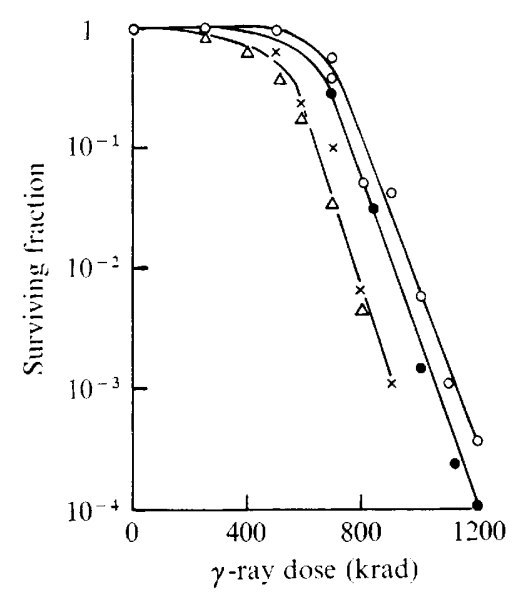

Fig. 5

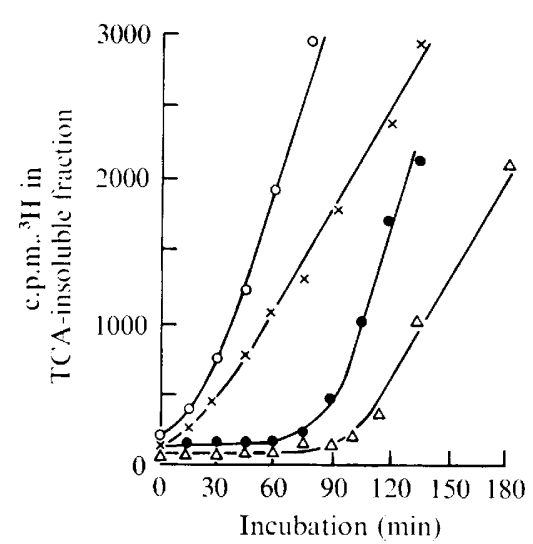

Fig. 6

Fig. 4. Ultraviolet irradiation survival curves of wild-type $(O)$ and the mutants tsI $(\times)$, ts2 ( $)$, and ts $3(\triangle)$ of Micrococcus radiodurans.

Fig. 5. $\gamma$-Irradiation survival curves of wild type $(O)$ and the mutants ts $I(\times)$, ts2 $(\odot)$, and ts3 $(\triangle)$ of Micrococcus radiodurans.

Fig. 6. Uptake of $\left[{ }^{3} \mathrm{H}\right]$ thymidine as a measure of DNA synthesis in Micrococcus radiodurans wildtype in an unirradiated culture at $30^{\circ}(x)$ and $39^{\circ}(O)$ and in a culture irradiated with 5300 ergs/ $\mathrm{mm}^{2}$ u.v. radiation at $30^{\circ}(\triangle)$ and $39^{\circ}(\mathbf{O})$. All the bacteria remain viable at this dose.

Table I. Frequency of transformation to streptomycin resistance of wild-type and three temperature-sensitive mutants of Micrococcus radiodurans following incubation of the recipient bacteria with DNA at $30^{\circ}$ and $39^{\circ}$

The bacteria were incubated with DNA for 2 to $3 \mathrm{~h}$ at $30^{\circ}$ or $15 \mathrm{~min}$ at $39^{\circ}$ since these times gave maximum transformation.

$\begin{array}{lcc}\text { Strain } & 30^{\circ} & 39^{\circ} \\ \text { Wild-type } & 3.0 \times 10^{-5} & 1.5 \times 10^{-6} \\ \text { tsI } & 3.0 \times 10^{-5} & 1.0 \times 10^{-5} \\ \text { ts2 } & 4.0 \times 10^{-5} & 4.0 \times 10^{-6} \\ \text { ts3 } & 4.0 \times 10^{-6} & 2.0 \times 10^{-6}\end{array}$

As a consequence of the continuing RNA and protein synthesis in the absence of DNA synthesis the mutant bacteria enlarged considerably but no cell division occurred.

Growth rates. The doubling times of the mutants were calculated from plots of increasing turbidity on a log scale against time. The mutants ts I and ts2 had doubling times during exponential growth at $30^{\circ}$ of $80 \mathrm{~min}$, the same as wild-type, while ts 3 was somewhat slower with a doubling time of $100 \mathrm{~min}$.

Radiation survival. The survival curves of the three mutants compared with those of wildtype are shown in Fig. 4 and 5. All three are very resistant to both u.v. and ionizing radiations although ts I and ts 3 appear slightly more sensitive than ts2.

Transformation of the temperature-sensitive mutants to streptomycin resistance. All three mutants were transformable and results for the transformation of the streptomycin-sensitive ts mutants to streptomycin resistance are given in Table $\mathrm{I}$, where they are compared with those for wild-type. The uptake of DNA was carried out at both $30^{\circ}$ and $39^{\circ}$ but at $39^{\circ}$ 

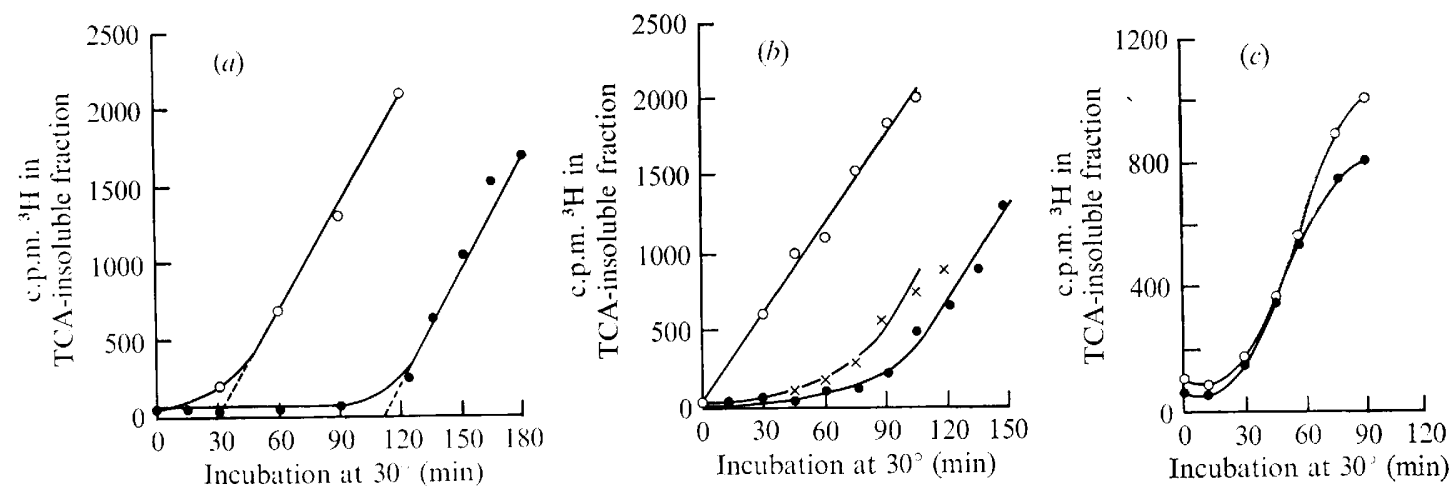

Fig. 7. Uptake of $\left[{ }^{3} \mathrm{H}\right]$ thymidine as a measure of DNA synthesis at $30^{\circ}$ in ts . (a) Unirradiated $(O)$ and u.v.-irradiated $\left(5300 \mathrm{ergs} / \mathrm{mm}^{2}\right)(\bullet)$ bacteria. $(b)$ Unirradiated $(O)$ and u.v.-irradiated bacteria which had been incubated for $50(\bullet)$ and $75(x)$ min at $39^{\circ}$ prior to uptake. $(c)$ Unirradiated $(\bigcirc)$ and u.v.-irradiated bacteria incubated for $140 \mathrm{~min}$ at $39^{\circ}$ prior to uptake $(\bullet)$.

Table 2. Frequency of transformation to temperature resistance of $t s \mathrm{I}, t s 2$, and ts 3 following incubation of the recipient bacteria with DNA from wild type, $t s \mathrm{I}, t s 2$, and $t s 3$

\begin{tabular}{|c|c|c|c|c|c|}
\hline \multirow[b]{2}{*}{ Strain } & \multicolumn{4}{|c|}{ DNA from } & \multirow[b]{2}{*}{ No DNA } \\
\hline & Wild-type & tsI & ts2 & ts 3 & \\
\hline ts I & $6.0 \times 10^{-5}$ & 0 & $6.0 \times 10^{-5}$ & $2.5 \times 10^{-5}$ & 0 \\
\hline ts2 & $7.0 \times 10^{-5}$ & $1 \cdot 2 \times 10^{-4}$ & 0 & $1.6 \times 10^{-5}$ & o \\
\hline ts3 & $2.0 \times 10^{-5}$ & $2.3 \times 10^{-5}$ & $3.0 \times 10^{-6}$ & 0 & o \\
\hline
\end{tabular}

maximum transformation was obtained following $15 \mathrm{~min}$ incubation compared with 2 to $3 \mathrm{~h}$ at $30^{\circ}$. In all cases the transformation frequency was reduced at $39^{\circ}$, from 20 -fold in the wild-type to twofold in ts 3 , although in the latter case the transformation frequency at $30^{\circ}$ was much lower than in wild-type, tsi, or ts2.

Transformation of temperature-sensitive strains to temperature resistance. The three mutants were exposed to DNA extracted from the wild-type, ts I, ts2, and ts3, under normal transformation conditions, and the bacteria then incubated at $39^{\circ}$. Each of the three ts mutants could be transformed to wild-type temperature resistance with DNA from either the wild-type or either of the other ts mutants. The results are shown in Table 2.

Excision repair of DNA at the restrictive temperature. The ability of ts mutants to repair their DNA at the restrictive temperature after u.v. or ionizing radiation damage was tested in the following way. Unirradiated bacteria incubated in broth in the presence of $\left[{ }^{3} \mathrm{H}\right]$ thymidine incorporate radioactive label into their DNA immediately as a consequence of normal DNA replication. When the bacteria have been irradiated there is a delay in the uptake of label since there is a delay in DNA synthesis (Swenson \& Setlow, 1966). Fig. 6 indicates that for wild-type Micrococcus radiodurans following a dose of $5300 \mathrm{ergs} / \mathrm{mm}^{2}$ u.v. radiation there is a delay in DNA synthesis of $65 \mathrm{~min}$ at $39^{\circ}$ and $80 \mathrm{~min}$ at $30^{\circ}$. The time of delay is linearly related to the radiation dose (Setlow \& Boling, 1965). By analogy with Escherichia coli we may assume that the delay in DNA synthesis is due to damage to DNA, although damage to the replication system itself may conceivably be responsible. If irradiated bacteria which cannot incorporate label at $39^{\circ}$ because they are unable to 

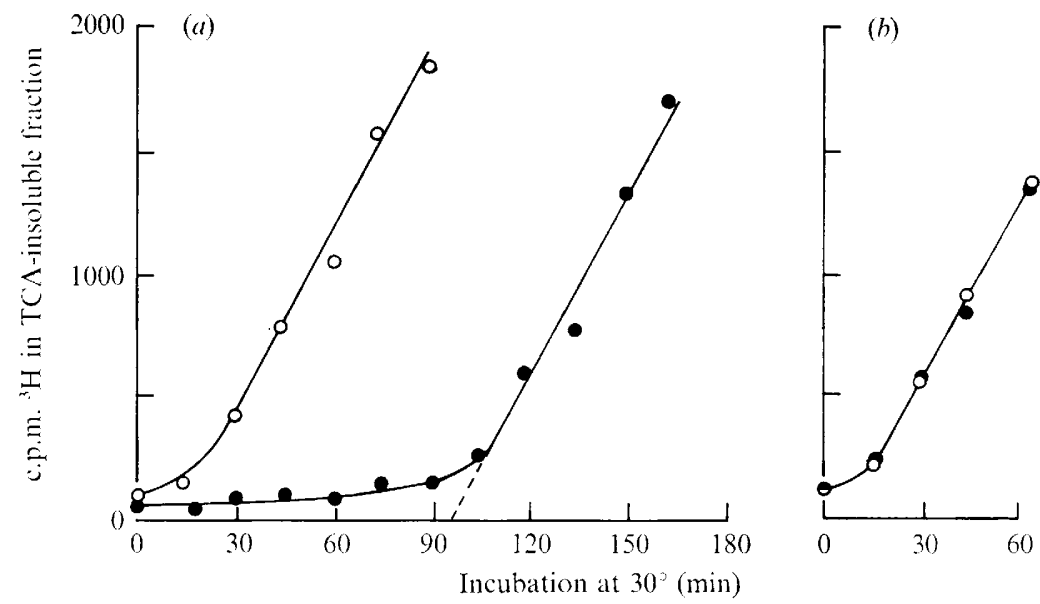

Fig. 8. Uptake of $\left[{ }^{3} \mathrm{H}\right]$ thymidine as a measure of DNA synthesis at $30^{\circ}$ in ts $\mathrm{I}$. (a) Unirradiated $(O)$ and $\gamma$-irradiated (I $75 \mathrm{krad}$ ) (O) bacteria. (b) Unirradiated $(O)$ and $\gamma$-irradiated bacteria incubated for $120 \mathrm{~min}$ at $39^{\circ}$ prior to uptake.
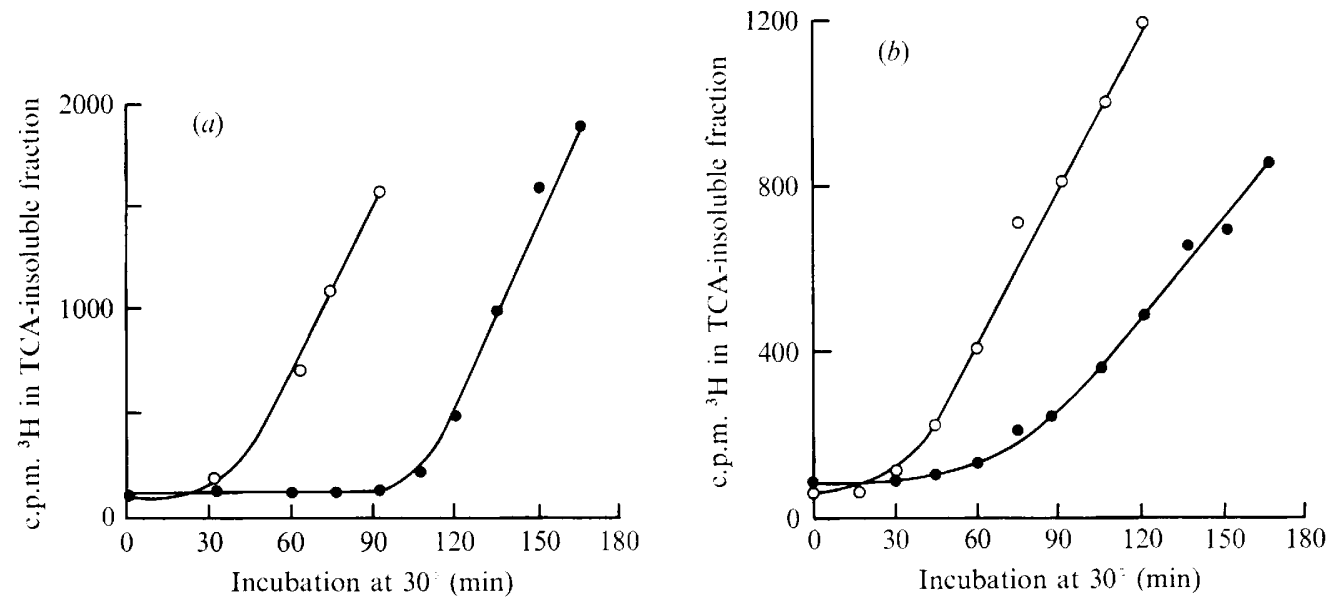

Fig. 9. Uptake of $\left[{ }^{3} \mathrm{H}\right]$ thymidine as a measure of DNA synthesis at $30^{\circ}$ in ts2. (a) Unirradiated $(O)$ and u.v.-irradiated $\left(5300 \mathrm{ergs} / \mathrm{mm}^{2}\right)(0)$ bacteria. $(b)$ Unirradiated $(O)$ and u.v.-irradiated bacteria incubated for $180 \mathrm{~min}$ at $39^{\circ}$ prior to uptake.

replicate their DNA, are nevertheless able to complete excision repair of damaged DNA, then when they are returned to a temperature of $30^{\circ}$ uptake of label will be immediate since normal DNA replication can resume immediately.

The three mutants were given sublethal doses of u.v. radiation that gave a reasonable delay in DNA synthesis. In all three cases the mutants were capable of carrying out some repair (presumably to their DNA) at $39^{\circ}$ so that when the bacteria were returned to the permissive temperature uptake of label was seen either immediately or after a shorter time interval than would have been observed if no repair had taken place.

Fig. 7 gives the data for ts I irradiated with $5300 \mathrm{ergs} / \mathrm{mm}^{2}$ u.v. radiation. At $30^{\circ}$ the delay in DNA synthesis was $80 \mathrm{~min}$. (Fig. 7a), the same as for wild-type. There was no indication of repair until $75 \mathrm{~min}$ at $39^{\circ}$ (Fig. $7 \mathrm{~b}$ ); after I $40 \mathrm{~min}$ repair was complete, since there was 

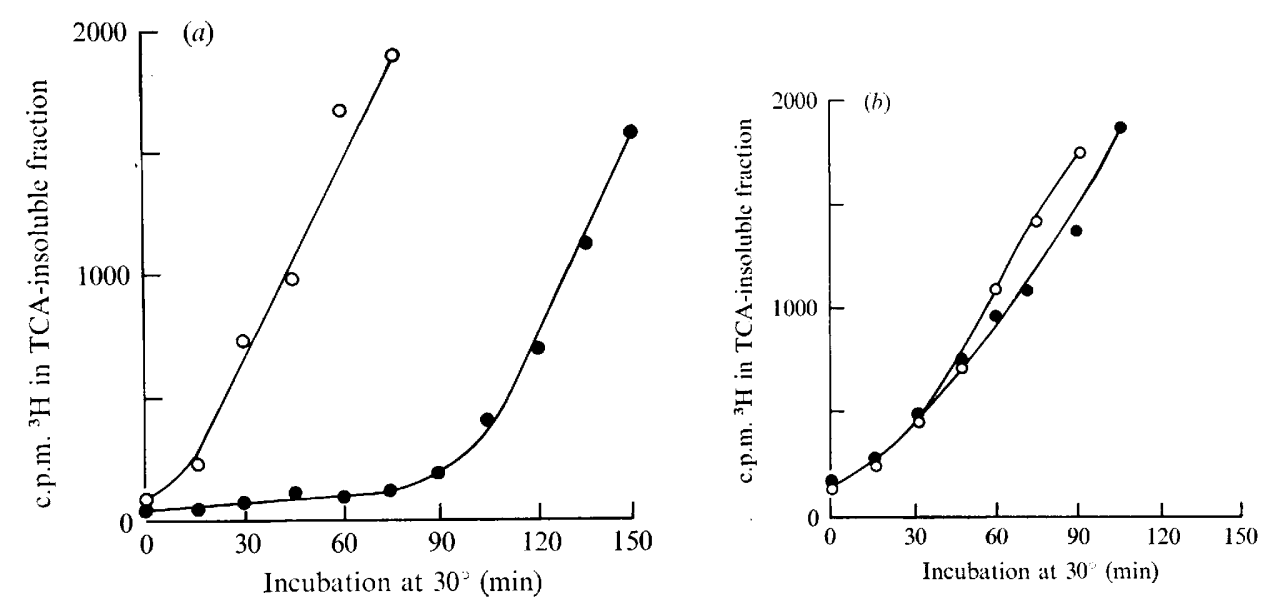

Fig. Io. Uptake of $\left[{ }^{3} \mathrm{H}\right]$ thymidine as a measure of DNA synthesis at $30^{\circ}$ in ts2. (a) Unirradiated $(O)$ and $\gamma$-irradiated (I75 krad) $(\bullet)$. (b) Unirradiated $(O)$ and $\gamma$-irradiated bacteria incubated for I 80 min at $39^{\circ}(\bullet)$ prior to uptake.

Table 3. Excision of thymine-containing pyrimidine dimers at $39^{\circ}$ in wild-type and ts mutants

The values represent the percentage of thymine as thymine-containing dimers in the TCAinsoluble fraction of the bacteria as a function of time of incubation of irradiated cells at $39^{\circ}$. The bacteria were given a u.v. dose of $5300 \mathrm{ergs} / \mathrm{mm}^{2}$.

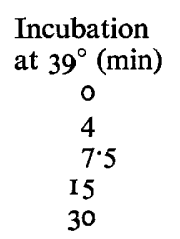

\begin{tabular}{|c|c|c|c|}
\hline \multicolumn{4}{|c|}{ Strain } \\
\hline Wild-type & tsI & ts2 & ts 3 \\
\hline 0.52 & 0.57 & 0.57 & 0.40 \\
\hline 0.16 & - & - & - \\
\hline 0.04 & - & 0.37 & - \\
\hline- & 0.14 & 0.14 & $0 . I_{I}$ \\
\hline - & 0.07 & - & 0.05 \\
\hline
\end{tabular}

uptake of radioactive label immediately the temperature was reduced (Fig. $7 c$ ). To test the repair of $\gamma$-radiation induced damage the bacteria were given a dose of $175 \mathrm{krad}$ which in the wild-type and tsI gave a delay in DNA synthesis of $85 \mathrm{~min}$ at $30^{\circ}$. By holding irradiated cells of tsi for $\mathrm{I} 20 \mathrm{~min}$ at $39^{\circ}$ uptake of label was immediate when the temperature was reduced to $30^{\circ}$ (Fig. 8).

When ts2 was irradiated with a dose of $5300 \mathrm{ergs} / \mathrm{mm}^{2}$ the delay in DNA replication at $30^{\circ}$ was $85 \mathrm{~min}$ (Fig. 9a). However, it was not possible to show complete repair for u.v.induced damage at the restrictive temperature; even after $180 \mathrm{~min}$ the delay was $30 \mathrm{~min}$ and uptake of label appeared to be at a slower rate than in the wild-type when it did resume (Fig. $9 b$ ). For $\gamma$-radiation induced damage repair was complete by $120 \mathrm{~min}$ incubation at $39^{\circ}$, since uptake of label at $30^{\circ}$ was normal (Fig. ro).

The delay in DNA replication at $30^{\circ}$ when ts 3 was irradiated with $5300 \mathrm{ergs} / \mathrm{mm}^{2}$ u.v. radiation was too long to be experimentally useful so the dose was halved to $2650 \mathrm{ergs} / \mathrm{mm}^{2}$ giving a delay of $70 \mathrm{~min}$. The results of raising the bacteria to a temperature of $39^{\circ}$ were similar to those of ts I after the higher dose. For $\gamma$-ray induced damage the time required appeared about the same as for tsi and ts2. A dose of $75 \mathrm{krad}$ gave a delay in DNA replication of about $40 \mathrm{~min}$ at $30^{\circ}$, and after $\mathrm{I} 20 \mathrm{~min}$ incubation at $39^{\circ}$ repair was almost complete. 
Irradiated cells did not show normal growth after repair at $39^{\circ}$ because RNA and protein synthesis continued at this temperature and the cells became swollen. As a result of this imbalance of synthesis, when the bacteria were returned to a temperature at which DNA replication was possible, the time required for the culture to reach the same status as one kept at $30^{\circ}$ in terms of viable units per $\mathrm{ml}$ and eventual optical density was equal to the time held at $39^{\circ}$. Thus it appeared that a period of DNA synthesis equal to the period the bacteria were held at the restrictive temperature was necessary before cell division could occur.

Excision of pyrimidine dimers from DNA at $39^{\circ}$. All three mutants were able to excise u.v.-induced pyrimidine dimers at the restrictive temperature. Table 3 shows the specific loss of thymine-containing dimers from the TCA-insoluble fraction of the irradiated bacteria compared with wild-type. The dimers are excised exponentially and when plotted the results indicate that wild-type can excise $90 \%$ of thymine containing dimers in $7 \mathrm{~min}$, while the three mutants take $32 \mathrm{~min}$, i.e. the process is 4 to 5 times faster in the wild-type at $39^{\circ}$.

\section{DISCUSSION}

The three temperature-sensitive mutants isolated were unable to replicate their DNA at $39^{\circ}$ as wild-type does but behaved typically in other respects although ts 3 did have a somewhat slower growth rate and lower frequency of transformation. The mutations leading to the isolation of these strains were either single mutations or very closely linked mutations since they could be transformed to wild-type temperature resistance with wild-type DNA with the frequency of transformation associated with the transfer of a single marker. The mutations were different since each of the ts strains could be transformed to temperature resistance with DNA from either of the other two. They also behaved differently at $39^{\circ}$ in terms of repair capability. The temperature-sensitive steps were not connected with the initiation of new rounds of DNA replication since DNA synthesis ceased immediately the bacteria were raised to the restrictive temperature. If the initiation step was involved then one would expect continuing DNA synthesis until all rounds of replication were complete (Maaløe \& Hanawalt, 196I).

The mutants, tsI and ts2, which have essentially the same radiation resistance as the wild-type, could be transformed for single genetic markers, e.g. streptomycin resistance, with the same frequency as the wild-type at $30^{\circ}$ so that the recombination mechanism operated normally at this temperature. This is in contrast to the radiation-sensitive mutant u.v. I7 isolated by the same technique which showed a reduced frequency of recombination (measured by transformation) commensurate with the reduction in radiation resistance and which was defective in recombination repair (Moseley \& Mattingly, 197I). The lower transformation frequency in ts 3 , which was not radiation-sensitive, may be connected with its slower growth rate rather than with a defect in recombination. This has been observed for other slow-growing strains of Micrococcus radiodurans.

Excision is possible in the mutants at the restrictive temperature. Hence it follows that the enzymes which have become temperature-sensitive, preventing the bacteria from replicating their DNA at $39^{\circ}$, are not involved in the excision step.

The repair at $39^{\circ}$ is not as efficient as in the wild-type. In the latter the delay in DNA synthesis following ionizing or u.v. radiation is shorter at $39^{\circ}$ than at $30^{\circ}$, indicating a faster rate of repair at $39^{\circ}$. In the mutants tsI and ts 2 the rate of repair at $30^{\circ}$, as indicated by the resumption of DNA synthesis, is the same as in the wild-type, but at $39^{\circ}$ even in those cases where excision repair appeared to be capable of completion, the time required was considerably longer than at $30^{\circ}$. One specific step in the excision repair of u.v.-induced damage 
is the removal of pyrimidine dimers. This step occurs in all three mutants at the same rate but is 4 to 5 times slower at $39^{\circ}$ than the corresponding excision in wild-type. The reduced rate of dimer excision is the same in all three mutants of Micrococcus radiodurans, even though in ts 3 the delay in DNA synthesis is about twice as long at $30^{\circ}$ as in ts I and ts 2 for the same u.v. dose and very much longer at $39^{\circ}$. Thus the delay is not dependent upon dimer excision but on some other factor. It could conceivably be due to a defect in the repolymerization step resulting from the ts 3 mutation. The only comparable work with ts DNA mutants has been that of Couch \& Hanawalt (1967) with Escherichia coli, who showed that repair replication after u.v. did occur at the restrictive temperature.

The question of whether recombination as well as excision repair occurs in the ts mutants at $39^{\circ}$ is difficult to answer since at $39^{\circ}$ the bacteria cannot grow and the temperature has to be reduced to $30^{\circ}$ for the genetic marker to be expressed. Integration of DNA could then occur at this lower temperature. In both wild-type and the mutants ts I and ts 2 the marker for streptomycin resistance can be transformed at $30^{\circ}$ with the normal frequency although in ts 3 it is somewhat lower. At $39^{\circ}$, however, the frequency is reduced considerably in all four strains. One possible method for showing recombination (by transformation) at $39^{\circ}$ in the mutants would be to transform them for temperature resistance so that the bacteria could be exposed to DNA from wild-type at $39^{\circ}$, overlaid in agar at $39^{\circ}$ and incubated at $39^{\circ}$. Such experiments have so far proved negative.

This investigation was supported by a grant from the Medical Research Council.

\section{REFERENCES}

Anderson, A. W., Nordan, H. C., Canin, R. F., Parrish, G. \& Duggan, D. (I956). Studies on a radioresistant micrococcus. Isolation, morphology, cultural characteristics, and resistance to gamma radiation. Food Technology ro, 575-578.

Boling, M. E. \& SetLow, J. K. (1966). The resistance of Micrococcus radiodurans to ultraviolet radiation. III. A repair mechanism. Biochimica et biophysica acta 123, 26-33.

Bollum, F. J. (I959). Thermal conversion of non-pairing deoxyribonucleic acid to primer. Journal of Biological Chemistry 234, 2733-2744.

BonhoefFer, F. \& SCHALler, H. (I965). A method for the selective enrichment of mutants based on the high UV sensitivity of DNA containing 5-bromouracil. Biochemical and Biophysical Research Communications 20, 93-97.

Couch, J. \& Hanawalt, P. C. (I967). DNA repair replication in temperature-sensitive DNA synthesis deficient bacteria. Biochemical and Biophysical Research Communications 29, 779-784.

Duggan, D. E., Anderson, A. W., Elliker, P. R. \& CAIN, R. F. (1959). Ultraviolet exposure studies on a gamma radiation resistant micrococcus isolated from food. Food Research 24, 376-382.

Hanawalt, P. C. \& HAYNES, R. H. (I965). Repair replication of DNA in bacteria: irrelevance of chemical nature of base defect. Biochemical and Biophysical Research Communications 19, 462-467.

MAaløE, O. \& HANAwalt, P. C. (196I). Thymine deficiency and the normal DNA replication cycle. Journal of Molecular Biology 3, I44-I55.

Moseley, B. E. B. (1967). The isolation and some properties of radiation-sensitive mutants of Micrococcus radiodurans. Journal of General Microbiology 49, 293-300.

Moseley, B. E. B. \& MAtTingly, A. (I97I). Repair of irradiated transforming deoxyribonucleic acid in wild type and a radiation-sensitive mutant of Micrococcus radiodurans. Journal of Bacteriology 105, 976-983.

Pettijohn, D. \& Hanawalt, P. (1964). Evidence for repair-replication of ultraviolet damaged DNA in bacteria. Journal of Molecular Biology 9, 395-4IO.

RupP, W. D. \& Howard-Flanders, P. (I968). Discontinuities in the DNA synthesised in an excision defective strain of Escherichia coli following ultraviolet irradiation. Journal of Molecular Biology $\mathbf{3}^{\mathbf{T}}$, 29I-304. 
SETLOW, J. K. \& BolING, M. E. (1965). The resistance of Micrococcus radiodurans to ultraviolet radiation. II. Action spectra for killing, delay in DNA synthesis, and thymine dimerisation. Biochimica et biophysica acta ro8, 259-265.

Setlow, R. B., Carrier, W. L. \& Bollum, F. J. (1965). Pyrimidine dimers in UV-irradiated poly dI:dC. Proceedings of the National Academy of Sciences of the United States of America 53, I I I I-I I 8.

Swenson, P. A. \& SetLow, R. B. (1966). Effect of ultraviolet radiation on macromolecular synthesis in Escherichia coli. Journal of Molecular Biology 15, 201-219.

WITKIN, E. M. (1969). Ultraviolet mutation and DNA repair. Annual Review of Microbiology 23, 487-5I4. 